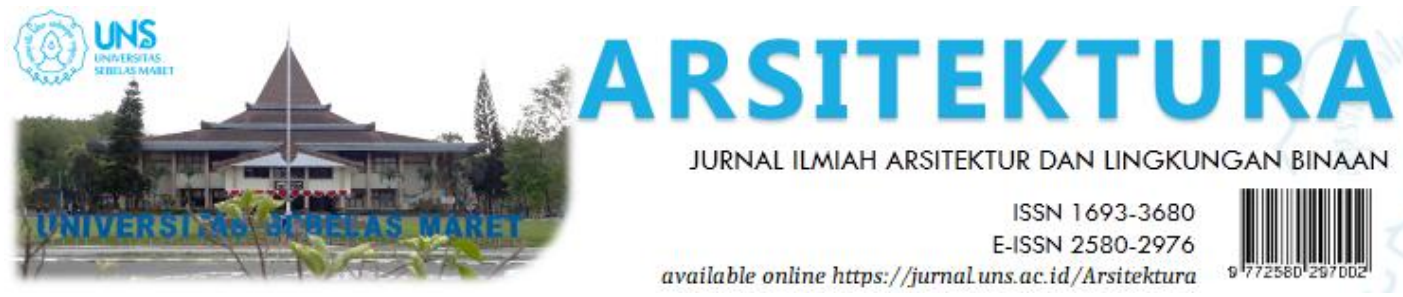

Volume 17 Issue 2 October 2019, pages:159-168

\title{
Redesain Rumah Sakit Umum Daerah (RSUD) Banyumas BerdasarkanPedoman Perancangan Rumah Sakit Peraturan Kementerian Kesehatan
}

\author{
Redesign of Banyumas District Hospital \\ Based on Hospital Designing Guidlines \\ of Health Ministerial Regulation
}

\author{
Salma Ali ${ }^{1 *}$, Ahmad Farkhan², Mohammad Muqoffa ${ }^{3}$ \\ Program Studi Arsitektur, Universitas Sebelas Maret ${ }^{1}$ \\ Email : salmabslmh@gmail.com* \\ Program Studi Arsitektur, Universitas Sebelas Maret ${ }^{2}$ \\ Program Studi Arsitektur, Universitas Sebelas Maret ${ }^{3}$
}

DOI: https://doi.org/10.20961/arst.v17i2.23884

Received: September 10, 2018 Revised: October 13, 2018 Accepted: March 30, 2019 Available online: October 31, 2019

\begin{abstract}
A hospital is a health care institution providing patient treatment, with a complex building system. In Indonesia, there is a regulation for hospital building system set by The Republic of Indonesia's Minister of Health arranging laws on hospital zoning plan, patient flow management, room requirement and size spesification, and structural and utilities system plan. Banyumas Dictrict Hospital is classified as type B academic hospital established in 1925. In order to develop hospital facilities and increase hospital bed capacity, Banyumas District Hospital demands area expansion and new buildings construction. This periodical development leads tol building system problems as zoning, hospital entrance and accessibility, and building flow system. Banyumas District Hospital is in need of post-occupancy-evaluation which is used as redeseign method, with the intention of restoring hospital to the regulation on hospital building by Minister of Health. Redesign result realized through the processing siteplan design, building design, and material application.
\end{abstract}

Keywords: hospital regulation, hospital building, Banyumas district hospital's facility

\section{PENDAHULUAN}

Kesehatan merupakan kebutuhan dasar setiap orang karena setiap aspek kehidupan berhubungan dengan kesehatan. Dalam upaya mendukung pembangunan di bidang kesehatan, diperlukan tenaga kesehatan serta sarana dan prasarana kesehatan yang sangat penting untuk menunjang kesehatan masyarakat, salah satunya adalah rumah sakit. Menurut Undang-Undang Republik Indonesia
Nomor 44 Tahun 2009 tentang Rumah Sakit, rumah sakit adalah institusi pelayanan kesehatan yang menyelenggarakan pelayanan kesehatan perorangan secara paripurna yaitu pelayanan kesehatan yang meliputi promotif, preventif, kuratif, dan rehabilitatif.

Rumah sakit umum diklasifikasikan menjadi 4 kelas yaitu kelas A, kelas B, kelas C, dan kelas D. Undang-Undang tentang Praktik Kedokteran (UUPK) tahun 2004 
mengamanatkan untuk perlu dirumuskannya standar profesi, standar pelayanan dan standar prosedur operasional dalam pelayanan kesehatan. Dengan demikian rumah sakit wajib memiliki sumber daya sarana, prasarana, alat dan sumber daya manusia yang kompetensinya sesuai dengan kelasnya. Menurut Berg, penyembuhan pasien secara rohani dan jasmani dipengaruhi oleh desain lingkungan fisiknya, dengan dibantu aspek lain berupa dukungan keluarga dan kecakapan staf rumah sakit (Ramadhani, 2018).

Setiap kelas rumah sakit mempunyai pedoman perancangan yang diterbitkan oleh Kementerian Kesehatan tahun 2012 berupa Pedoman Teknis Bangunan Rumah Sakit. Pedoman ini mengatur tentang pengelompokan area fasilitas (zonasi) rumah sakit, perancangan alur sirkulasi pasien, kebutuhan dan ukuran ruang rumah sakit, serta perancangan struktur dan utilitas rumah sakit.

Aksesibilitas di lingkungan rumah sakit ditunjukan dari kemudahan pasien dalam mendapatkan perawatan. Hal ini dapat dilihat dari pelayanan yang diberikan serta fasilitas umum yang tersedia didalamnya (Pudjiantoro, 2008). RSUD Banyumas diakses dari Jalan Rumah Sakit, yaitu jalan kecil persimpangan jalan besar Jalan Jend. Gatot Subroto, yang merupakan akses dari semua jenis kendaraan rumah sakit. Ambulan, kendaraan pengunjung, mobil jenazah, dan kendaraan servis mengakses rumah sakit melalui satu pintu utama. Penumpukan kendaraan dalam satu akses membuat pintu masuk kendaraan rumah sakit padat, tidak adanya privasi setiap jenis kegiatan, serta tidak terciptanya karakteristik sirkulasi setiap jenis kendaraan, yaitu:

a. Kendaraan gawat darurat, mempunyai jalur khusus yang mudah dijangkau dan bebas hambatan.

b. Kendaraan umum, mempunyai jalur yang mudah dikenali dan menarik.

c. Kendaraan servis dan jenazah, mempunyai jalur khusus yang tidak dilalui oleh kendaraan umum untuk alasan psikologis pasien.

Pengelompokan zonasi yang tepat akan mendukung efektivitas dan efisiensi kegiatan yang berlangsung di dalam rumah sakit, dengan memberikan kedekatan ruang-ruang yang saling membutuhkan kedekatan, dan memisahkan ruang-ruang yang membutuhkan pemisahan (PT Global Rancang Selaras, 2010). Pengelompokan zonasi rumah sakit ditentukan berdasarkan tingkat risiko terjadinya penularan penyakit, zonasi berdasarkan privasi dan zonasi berdasarkan pelayanan. Zonasi berdasarkan tingkat risiko penularan penyakit terdiri dari zona dengan risiko rendah, zona dengan risiko sedang, zona dengan risiko tinggi, dan zona dengan risiko sangat tinggi. Zona berdasarkan privasi kegiatan terdiri dari zona publik, zona semi publik, dan zona privat. Zonasi berdasarkan pelayanan terdiri dari pelayanan medik dan perawatan, pelayanan penunjang dan operasional, dan pelayanan administrasi (Kementerian Kesehatan, 2012).

Sirkulasi dalam rumah sakit terbagi berdasarkan kelompok kegiatan pengguna yaitu pasien dan tenaga medis (Kementerian Kesehatan, 2012), serta kelompok transportasi pengguna yaitu sepeda, troli barang, brankar, dan kursi roda. Sirkulasi servis dirancang agar tidak memotong pergerakkan pengguna umum. Kegiatan dalam bangunan RSUD Banyumas yang mempunyai tapak yang cukup luas dihubungkan oleh koridor yang dilalui untuk sirkulasi semua pengguna bangunan. Koridor rumah sakit yang digunakan oleh pejalan kaki dan pengguna transportasi mempunyai dimensi yang terbatas, dan material penutup lantai sejenis.

Berdasarkan jenis pelaku sirkulasi, kebutuhan besaran koridor berbeda-beda. Menurut standar Data Arsitek (Ernst Neufert, 2002), beberapa dimensi pelaku sirkulasi yaitu:

a. Dimensi orang berjalan : $60 \mathrm{~cm}$

b. Dimensi troli barang : $90 \mathrm{~cm}$

c. Dimensi brankar : $95 \mathrm{~cm}$

Dari uraian tersebut, evaluasi RSUD Banyumas perlu dilakukan, untuk mengembalikan desain RSUD Banyumas yang sesuai dengan standar dari Peraturan Kementerian Kesehatan Republik Indonesia.

\section{METODE}

Metode penelitian yang digunakan adalah penelitian evaluasi melalui pendekatan deskriptif kualitatif. Evaluasi purna huni pada 
RSUD Banyumas berupa evaluasi aspek fungsional dan perilaku. Aspek fungsional merupakan evaluasi terhadap fungsi dan fisik bangunan yang mempengaruhi efisiensi bangunan, dan evaluasi aspek perilaku merupakan hubungan antara pengguna bangunan dengan lingkungan fisiknya (Moore, 1994).

Aspek fungsional berupa evaluasi tapak dan peruangan rumah sakit. Evaluasi tapak rumah sakit berupa akses masuk rumah sakit dan sirkulasi kelompok kendaraan. Evaluasi peruangan berupa tata massa dan zonasi rumah sakit. Aspek perilaku berupa evaluasi koridor rumah sakit yang berkaitan dengan alur sirkulasi pengguna bangunan.

Dari hasil penelitian evaluasi purna huni, didapatkan data sebagai pertimbangan dan rekomendasi untuk proses perencanaan dan perancangan redesain RSUD Banyumas. Dasar yang digunakan dalam mengevaluasi RSUD Banyumas berupa peraturan dari Kementerian KesehatanTahun 2012 dalam Pedoman Teknis Bangunan Rumah Sakit Kelas B, yang mengatur tentang pengolahan tapak dan peruangan rumah sakit.

\section{HASIL DAN PEMBAHASAN}

Penerapan desain RSUD Banyumas berdasarkan pedoman perancangan bangunan rumah sakit diterapkan pada pengolahan tapak dan peruangan rumah sakit.

\section{a. Perluasan rumah sakit}

Tapak eksisting rumah sakit hanya dapat diakses dari satu pencapaian yaitu Jalan Rumah Sakit untuk akses utama rumah sakit dan satu pencapaian khusus pengunjung unit VIP.

Menurut manajemen RSUD Banyumas, pelebaran tapak rumah sakit ke arah timur dilakukan dengan tujuan mendapatkan titik pencapaian yang baru, yaitu dari Jalan Banyumas - Kemranjen (lihat Gambar 1).

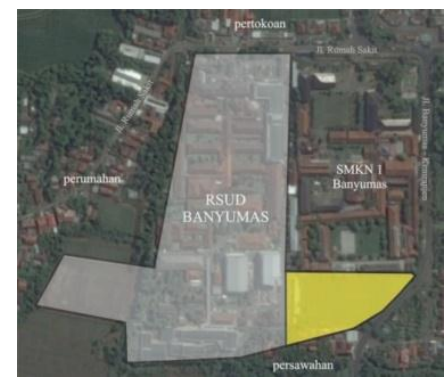

Gambar 1.Perluasan Tapak RSUD Banyumas ke Arah Timur

\section{b. Pencapaian rumah sakit}

Pencapaian eksisting RSUD Banyumas dari Jalan Rumah Sakit berupa akses bagi seluruh jenis kendaraan pengguna rumah sakit, yaitu ambulan, kendaraan pengunjung, kendaraan pengelola, dan kendaraan servis dan jenazah. Akses bagi kendaraan pengunjung unit VIP berada di Jalan Rumah Sakit bagian barat, ditunjukkan pada Gambar 2:

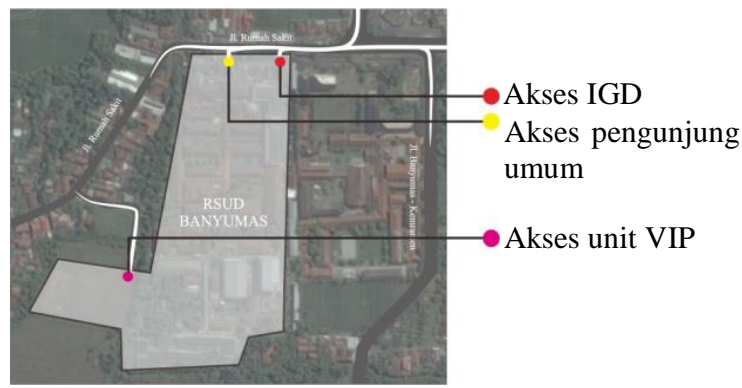

Gambar 2. Pencapaian Eksisting RSUD Banyumas

Jalan Rumah Sakit mempunyai gapura petunjuk lokasi RSUD Banyumas pada bagian depan. Rumah sakit dicapai dari Jalan Rumah Sakit sejauh $70 \mathrm{~m}$ yang dapat diakses oleh kendaraan pribadi dan dengan berjalan kaki. Jalan Rumah Sakit tidak dilalui okeh kendaraan umum (lihat Gambar 3).

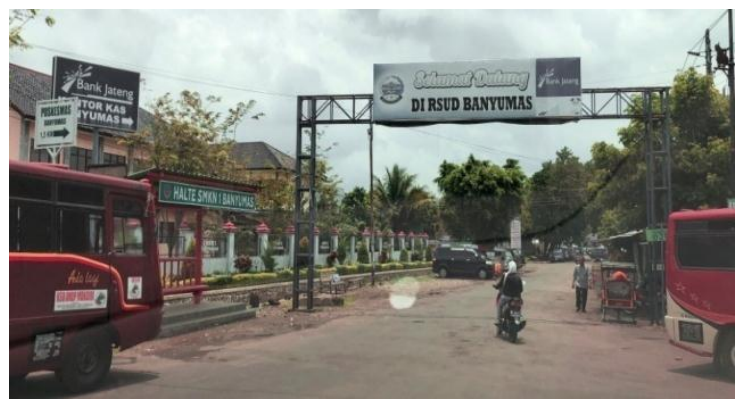

Gambar 3.Akses Menuju RSUD Banyumas Melalui Jalan Rumah Sakit 
Jalan Rumah Sakit mempunyai lebar $7 \mathrm{~m}$ yang digunakan untuk sirkulasi dua arah kendaraan. Jalan Rumah Sakit tidak hanya dilalui oleh pengunjung rumah sakit, jalan dilalui oleh penduduk setempat untuk mengakses pemukiman di sekitar rumah sakit. Di sepanjang jalan, terdapat kios dan PKL, serta lahan yang dijadikan parkiran bagi pengunjung rumah sakit (lihat Gambar 4).

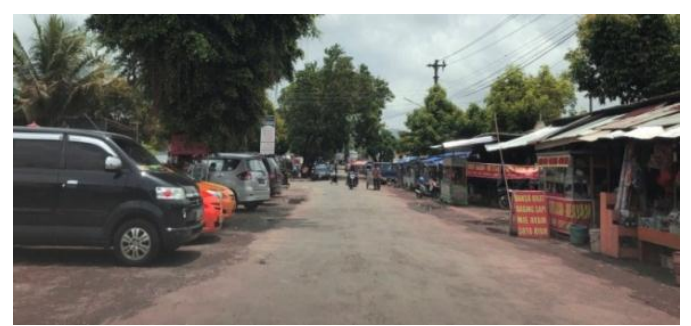

Gambar 4.Kondisi Jalan Rumah Sakit

Berdasarkan rencana manajemen rumah sakit untuk melebarkan tapak rumah sakit ke arah timur, rumah sakit mendapatkan titik pencapaian baru yaitu dari Jalan Banyumas Kemranjen. Selain untuk mendapatkan pencapaian baru, pelebaran tapak betujuan untuk pengembangan fasilitas dan penambahan kapasitas tempat tidur rumah sakit. Pemisahan akses kendaraan pengguna RSUD Banyumas didasarkan dari karakteristik dan kebutuhan sirkulasi kendaraan (lihat Gambar 5).

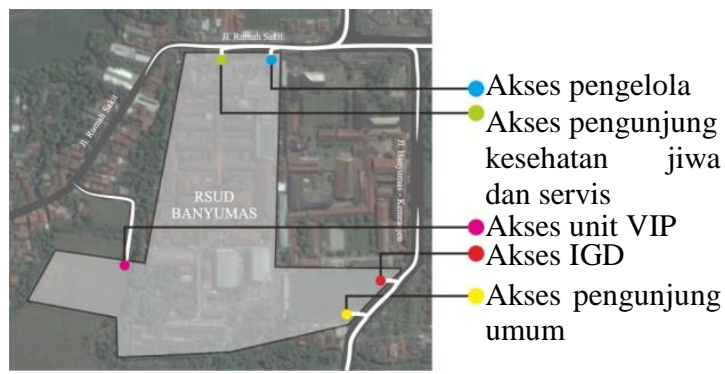

Gambar 5. Pemisahan Akses RSUD Banyumas

\section{c. Sirkulasi tapak rumah sakit}

Sirkulasi tapak rumah sakit berupa sirkulasi kendaraan pengguna dalam mengakses fasilitas rumah sakit. Secara umum, pada Gambar 6 ditunjukkan sirkulasi kendaraan pengguna yang diakses dari akses utama rumah sakit.

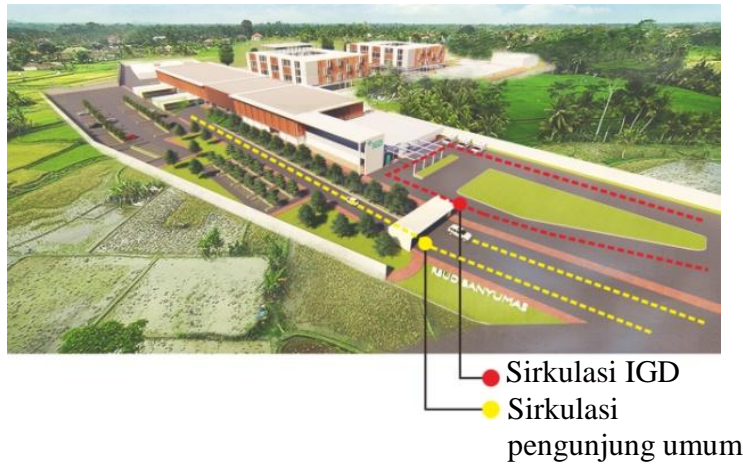

Gambar 6.Sirkulasi Kendaraan Dari Akses Utama RSUD Banyumas

Sirkulasi kendaraan pengguna dalam tapak dibedakan berdasarkan fasilitas rumah sakit, yaitu sirkulasi IGD, sirkulasi pengunjung poliklinik, sirkulasi pengunjung rawat inap, sirkulasi servis, dan sirkulasi pengelola (lihat lampiran 1).

Pada fasilitas rawat inap, kendaraan pengunjung mengakses basement untuk parkir dan drop-off, seperti pada Gambar 7:

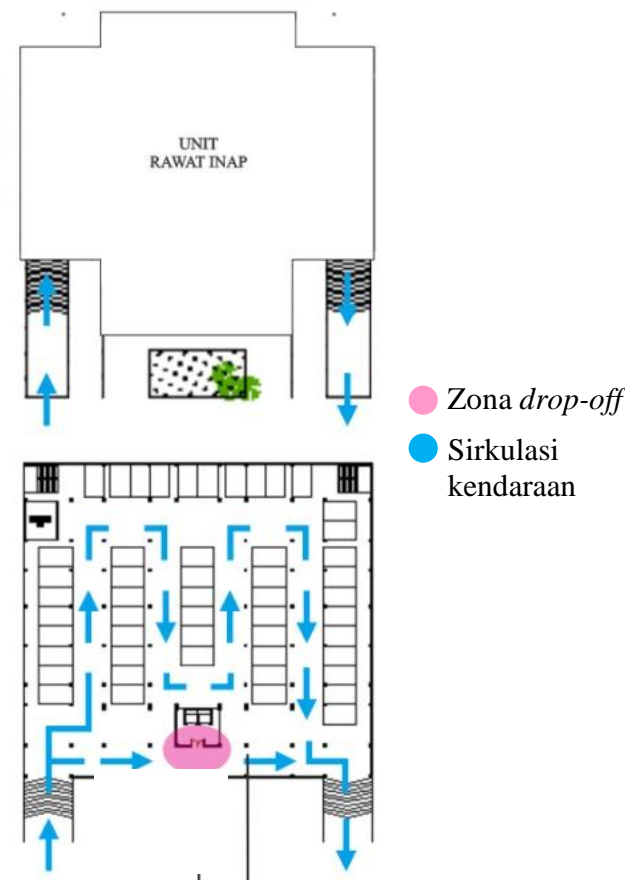

Gambar 7. Sirkulasi Kendaraan Pengunjung Rawat Inap

\section{d. Zonasi rumah sakit}

Zonasi rumah sakit ditentukan berdasarkan pola massa bangunan (vertikal dan horizontal), tingkat risiko terjadinya penularan penyakit, kebutuhan privasi kegiatan, dan jenis pelayanan rumah sakit. 
Pada RSUD Banyumas, pola massa bangunan berupa pola horizontal dikarenakan tapak rumah sakit yang luas dapat dikembangkan secara horizontal. Penataan massa rumah sakit menggunakan massa majemuk. Jenis pelayanan dikelompokkan menjadi kelompok pelayanan medik dan perawatan, pelayanan penunjang dan operasional, dan pelayanan administrasi. Gambar 8 menunjukkan zonasi RSUD Banyumas:

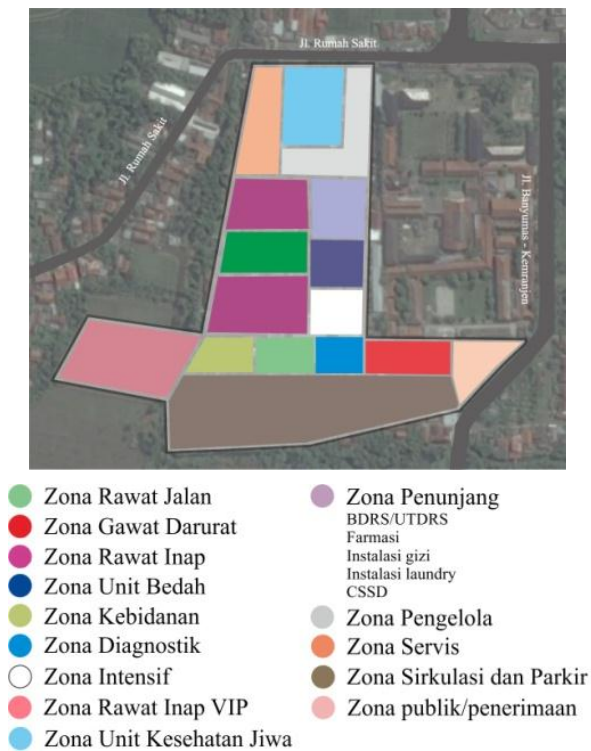

Gambar 8.Zonasi RSUD Banyumas

Tujuan ditentukannya zonasi rumah sakit adalah untuk menghasilkan pola hubungan ruang yang efektif. Ruang-ruang yang dikelompokkan dalam satu zona mempunyai hubungan yang harus didekatkan, serta zona yang tidak boleh berdekatan harus dijauhkan. Gambar 9 menunjukkan pola hubungan ruang RSUD Banyumas:

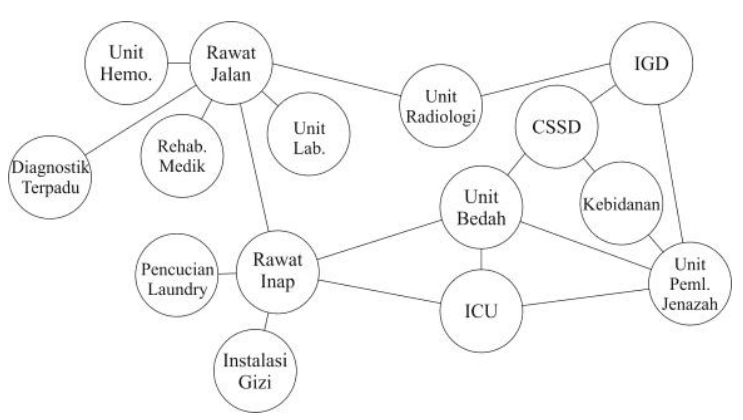

Gambar 9. Pola Hubungan Ruang RSUD Banyumas
Ruang-ruang pada RSUD Banyumas dikelompokkan berdasarkan zonasi rumah sakit. Berdasarkan pengelompokkan fasilitas rumah sakit, Tabel 1 menunjukkan besaran ruang RSUD Banyumas.

Tabel 1.Besaran Ruang RSUD Banyumas

\begin{tabular}{|c|c|c|}
\hline No. & Unit/Fasilitas & $\begin{array}{l}\text { Luasan } \\
\text { Ruang }\end{array}$ \\
\hline 1. & Poliklinik & $958 \mathrm{~m}^{2}$ \\
\hline 2. & Instalasi Gawat Darurat & $750,8 \mathrm{~m}^{2}$ \\
\hline 3. & Instalasi Rawat Inap (IRNA) & $1124 \mathrm{~m}^{2}$ \\
\hline 4. & Unit Perawatan Intensif (ICU) & $316 \mathrm{~m}^{2}$ \\
\hline 5. & $\begin{array}{l}\text { Ruang Operasi (COT/Central } \\
\text { Operation Theatre) }\end{array}$ & $375,5 \mathrm{~m}^{2}$ \\
\hline 6. & Unit Kebidanan & $660,6 \mathrm{~m}^{2}$ \\
\hline 7. & Ruang Rehabilitasi Medik & $509 \mathrm{~m}^{2}$ \\
\hline 8. & Ruang Radiodiagnostik & $208 \mathrm{~m}^{2}$ \\
\hline 9. & Ruang Diagnostik Terpadu & $167,5 \mathrm{~m}^{2}$ \\
\hline 10. & Unit Farmasi & $319 \mathrm{~m}^{2}$ \\
\hline 11. & Laboratorium & $300 \mathrm{~m}^{2}$ \\
\hline 12. & Ruang Hemodialisa & $314,5 \mathrm{~m}^{2}$ \\
\hline 13. & $\begin{array}{l}\text { Bank Darah/Unit Transfusi } \\
\text { Darah (BDRS/UTDRS) }\end{array}$ & $164 \mathrm{~m}^{2}$ \\
\hline 14. & Pemulasaraan Jenazah & $456 \mathrm{~m}^{2}$ \\
\hline 15. & $\begin{array}{l}\text { Ruang Sterilisasi Pusat } \\
\text { (CSSD) }\end{array}$ & $233 \mathrm{~m}^{2}$ \\
\hline 16. & Ruang Pencucian Laundry & $182 \mathrm{~m}^{2}$ \\
\hline 17. & Instalasi Gizi & $239 \mathrm{~m}^{2}$ \\
\hline 18. & Ruang Sanitasi & $107 \mathrm{~m}^{2}$ \\
\hline 19. & Ruang Pemeliharaan Sarana & $117 \mathrm{~m}^{2}$ \\
\hline 20. & $\begin{array}{l}\text { Pelayanan Pendidikan dan } \\
\text { Penelitian }\end{array}$ & $165 \mathrm{~m}^{2}$ \\
\hline 21. & $\begin{array}{l}\text { Kantor Manajemen Rumah } \\
\text { Sakit }\end{array}$ & $161 \mathrm{~m}^{2}$ \\
\hline 22. & Fasilitas Umum & $802 \mathrm{~m}^{2}$ \\
\hline & Total & $8628,9 \mathrm{~m}^{2}$ \\
\hline
\end{tabular}

\section{e. Sirkulasi pengguna rumah sakit}

Sirkulasi pengguna dalam rumah sakit diwadahi dalam koridor rumah sakit. Koridor menghubungkan ruang-ruang pada rumah sakit, dan digunakan oleh semua jenis pengguna rumah sakit. Sirkulasi rumah sakit berdasarkan jenis pengguna yaitu pengunjung, staf medis, dan servis, dan sirkulasi rumah sakit berdasarkan sarana yang digunakan pengguna berupa sepeda, brankar, kursi roda, dan troli barang.

Sirkulasi berdasarkan jenis pengguna dipisahkan, karena alasan privasi, kecepatan sirkulasi, dan mengurangi kepadatan. Sirkulasi pengunjung berada di area tengah tapak untuk 
mengakses ruang dari bagian depan, dan sirkulasi servis berada di area samping untuk mengakses ruang dari bagian belakang (lihat Lampiran 2).

Sirkulasi RSUD Banyumas juga dibedakan berdasarkan sarana yang digunakan pengguna bangunan. Sepeda, brankar, kursi roda, dan troli barang mempunyai alur sirkulasi yang berbeda-beda (lihat Gambar 10).

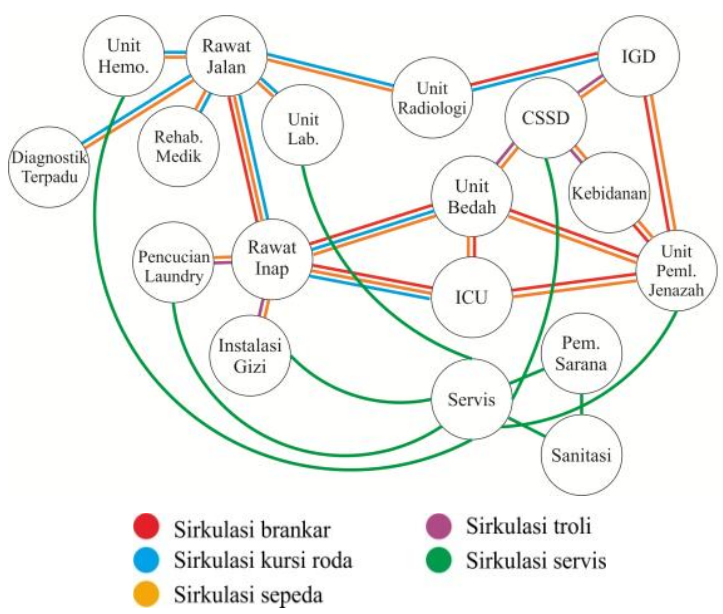

Gambar 10. Sirkulasi Sarana Pengguna RSUD Banyumas

Koridor rumah sakit yang berfungsi mewadahi bermacam sirkulasi pengguna rumah sakit dipisahkan sesuai dengan karakteristiknya. Koridor rumah sakit yang dilewati oleh pengguna bangunan dengan sarana transportasi mempunyai karakteristik material lantai anti selip dan kebutuhan penggunaan ramp pada perbedaan ketinggian lantai. Jalur untuk pejalan kaki mempunyai karakteristik penggunaan pegangan rambat (handrail) di sepanjang koridor rumah sakit. Dalam perancangan koridor RSUD Banyumas, pegangan rambat (handrail) juga digunakan sebagai pemisah jalur pejalan kaki dengan jalur sarana transportasi. Berikut adalah gambar desain koridor rumah sakit dengan pemisahan jalur bagi setiap penggunanya (lihat Gambar 11).

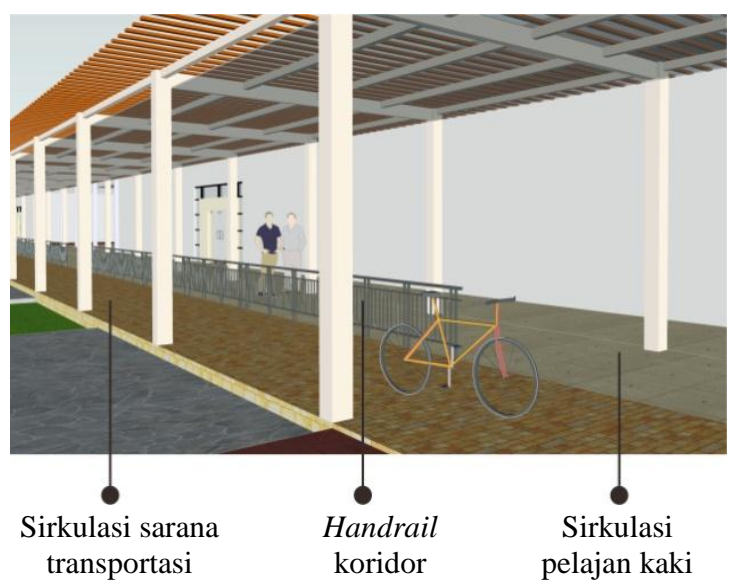

Gambar 11. Koridor RSUD Banyumas

\section{KESIMPULAN}

Berdasarkan pembahasan yang dilakukan sebelumnya, evaluasi purna huni RSUD Banyumas dengan mengkaji kembali Peraturan Kementerian Kesehatan Tahun 2012 diharapkan mampu mengembalikan RSUD Banyumas sesuai pedoman, sehingga dapat menjadi lebih baik dalam memberikan fasilitas penyembuhan bagi pasien di rumah sakit.

Redesain RSUD Banyumas yang dilakukan berupa evaluasi pencapaian rumah sakit, penataan zonasi rumah sakit, dan sirkulasi pengguna rumah sakit. Pertama, evaluasi dalam pencapaian rumah sakit dengan melebarkan tapak rumah sakit ke arah timur dilakukan agar mendapatkan titik pencapaian yang baru. Hasil dari evaluasi pencapaian berupa perancangan akses rumah sakit yang baru, yaitu pemisahan akses kendaraan berdasarkan karakteristik masing-masing sirkulasi kendaraan. Kedua, penataan kembali zonasi rumah sakit dilakukan dengan menempatkan zona-zona yang berhubungan berdekatan, dan zona-zona yang tidak berhubungan atau tidak diperbolehkan berdekatan ditempatkan berjauhan. Ketiga, pemisahan jalur sirkulasi pada koridor rumah sakit menurut kebutuhan penggunanya dilakukan dengan memisahkan alur sirkulasi pengunjung dengan petugas rumah sakit, dan mengaplikasikan material lantai yang berbeda bagi pejalan kaki dan pengguna sarana transportasi koridor. Hasil redesain RSUD Banyumas dapat dilihat pada siteplan RSUD Banyumas, pada Lampiran. 


\section{REFERENSI}

Glabella Ersyara Ramadhani, Ahmad Farkhan, Leny Pramesti. (2018). Penerapan Physical Outcome Theory pada Desain Rumah Sakit Ibu dan Anak di Surakarta. Arsitektura, Volume 16 Nomor 1 April, DOI: http://dx.doi.org/10.20961/arst.v16i 1.17236.

Neufert, Ernst. (2002). Data Arsitek jilid II.

Kementerian Kesehatan Republik Indonesia. (2012). Pedoman Teknis Bangunan Rumah Sakit Kelas B.

Pemerintah Kabupaten Banyumas. (2016). Laporan Kinerja Instansi Pemerintah (LKjIP) RSUD Banyumas.

Pudjiantoro, Rahardjanto. (2008). Pengembangan Pelayanan RumahSakit Umum Daerah Tugurejo-Semarang. Semarang: Universitas Diponegoro.

PT. Global Rancang Selaras. (2010). Arsitektur Rumah Sakit: Yogyakarta. 


\section{LAMPIRAN}

Lampiran 1

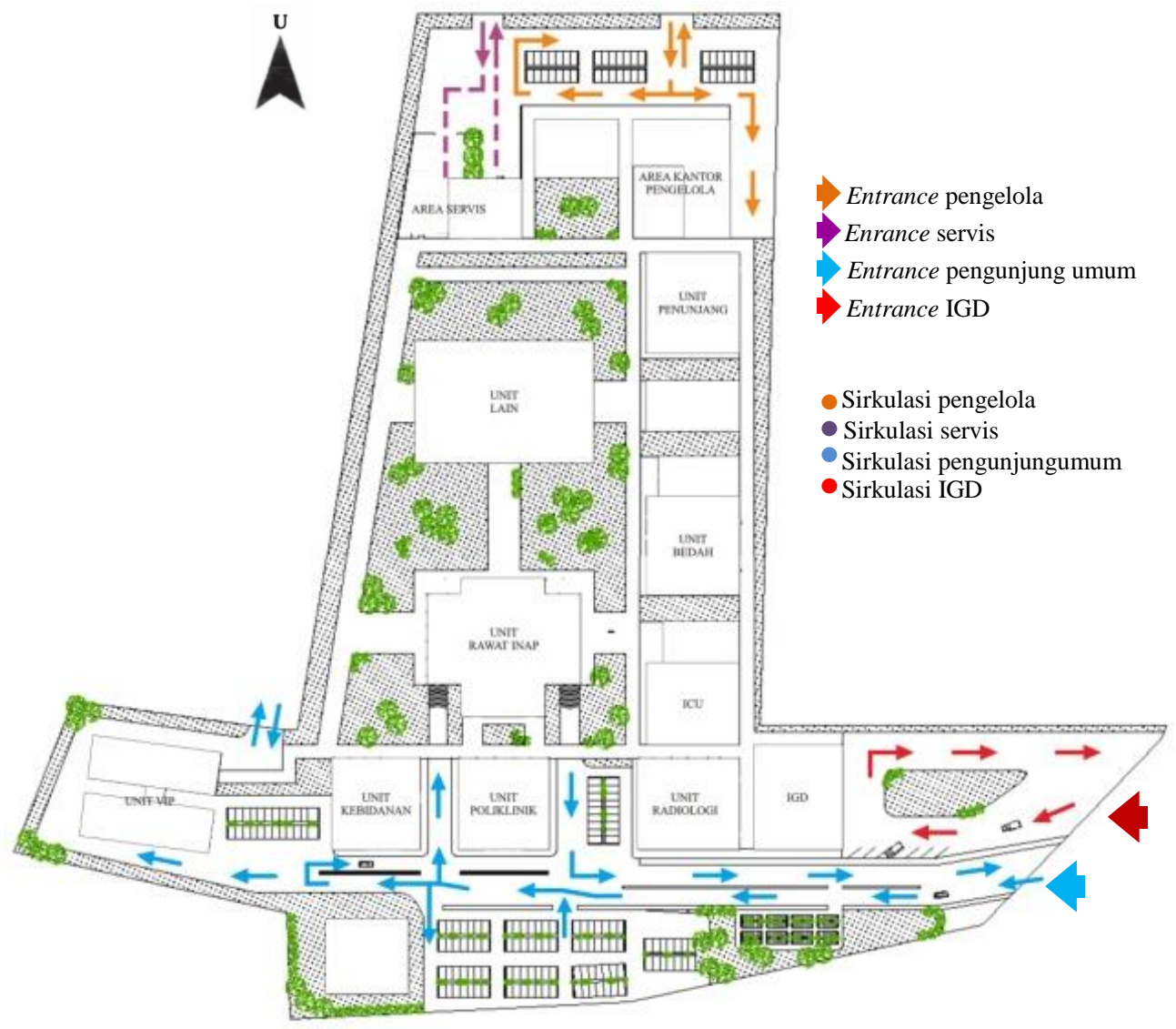

Gambar Sirkulasi Kendaraan Pengelola, Servis, Pengunjung Umum, dan IGD pada Tapak RSUD Banyumas 


\section{Lampiran 2}

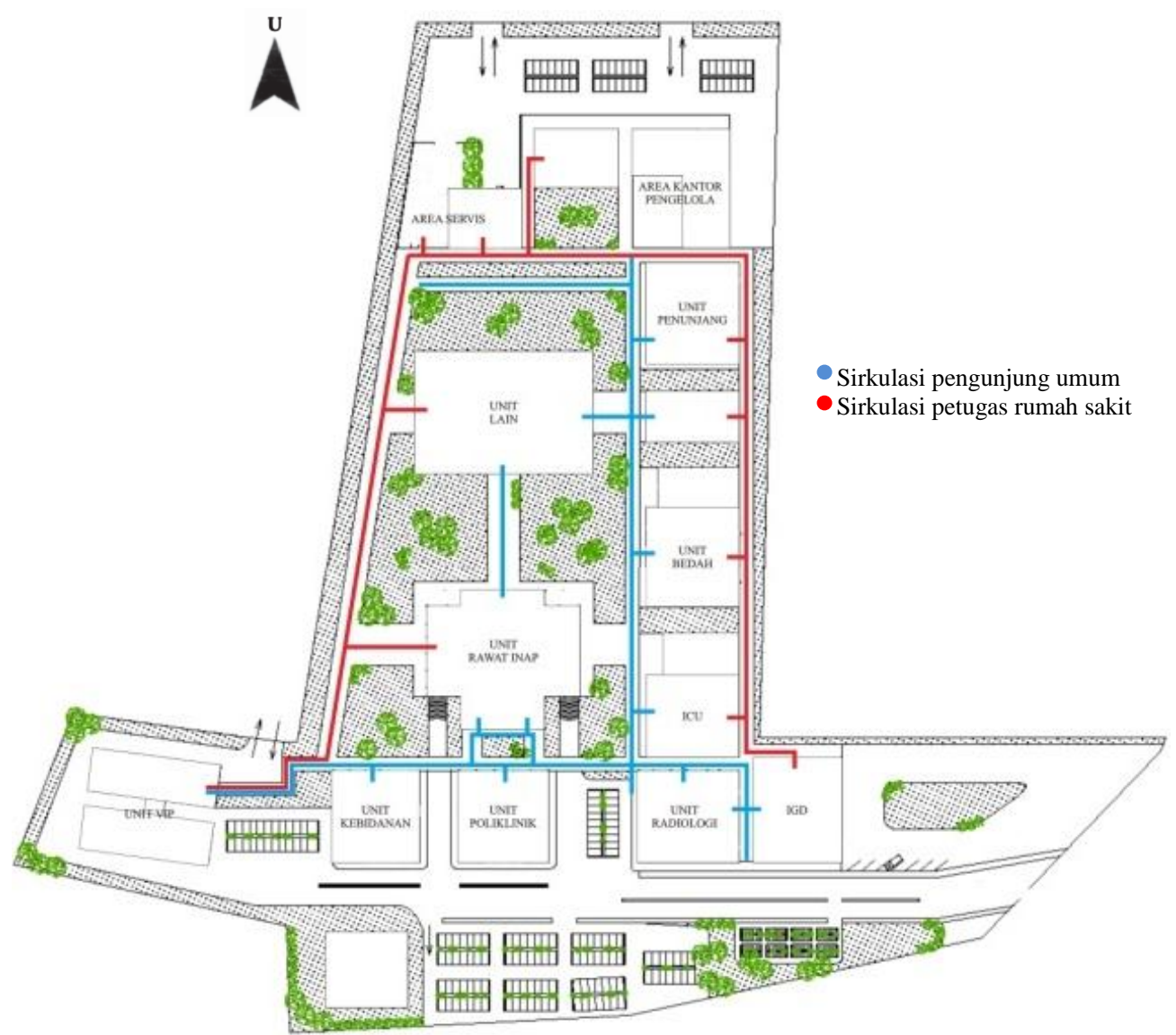

Gambar Sirkulasi Pengunjung Umum dan Petugas Rumah Sakit pada koridor RSUD Banyumas 


\section{Lampiran 3}

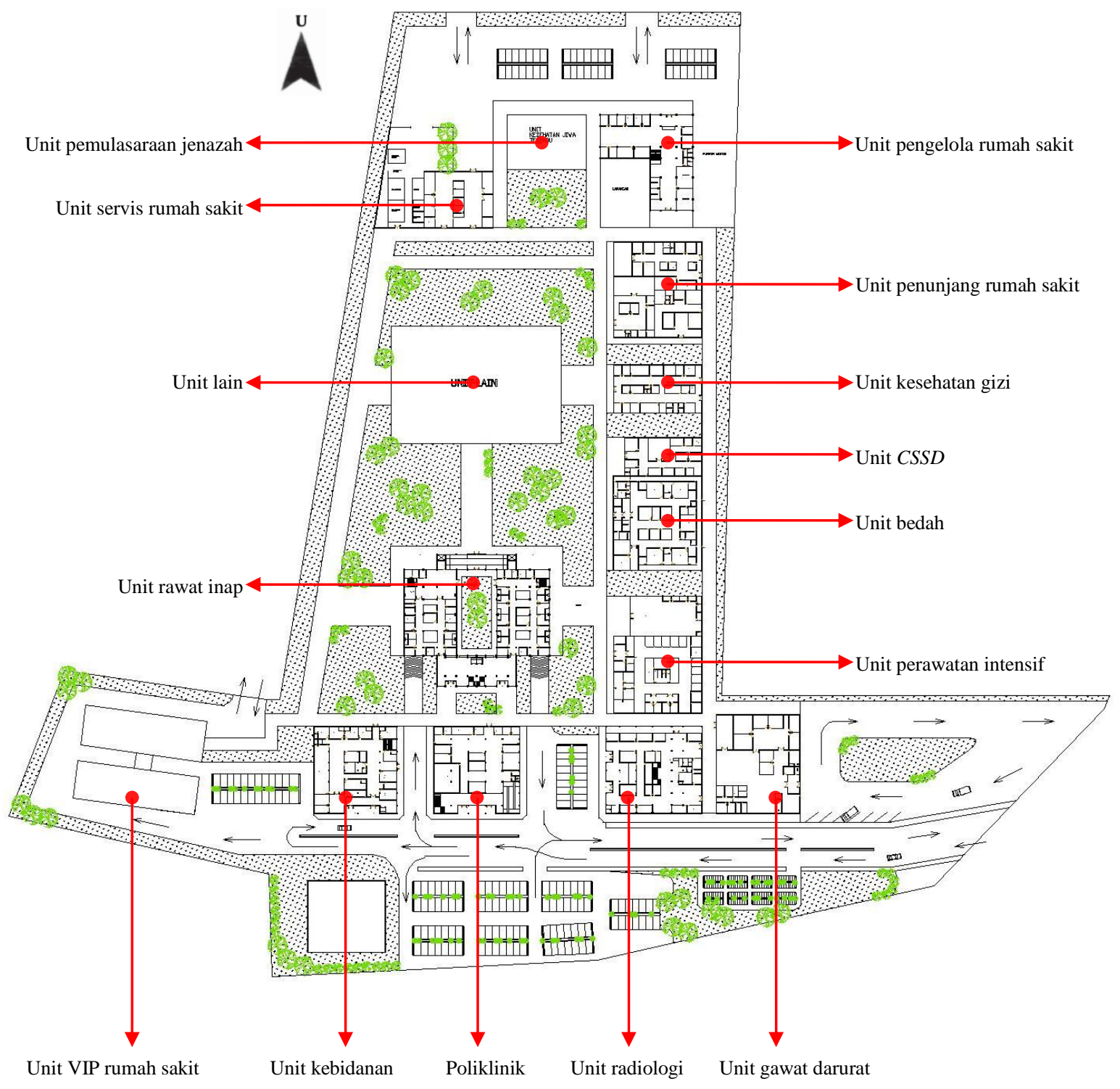

Gambar Siteplan RSUD Banyumas 